\title{
Effect of Zinc Ion on Human Chorionic Gonadotropin-Stimulated in Vitro Production of Cyclic AMP and Testosterone by Rat Testis
}

\author{
YOSHIKAZU NISHI, ${ }^{(30)}$ SHUICHI HATANO, KATSUAKI AIHARA, HIROYASU OKAHATA, \\ HIROSHI KAWAMURA, KO TANAKA, YUKITAKA MIYACHI, AND TOMOFUSA USUI \\ Department of Pediatrics, Hiroshima University School of Medicine, [Y.N., S.H., K.A., H.O., T.U.] and \\ Department of Internal Medicine, Hiroshima University School of Medicine, Minami-ku, Hiroshima, Japan \\ [H.K., K.T.]; and Department of Internal Medicine, Shizuoka General Hospital, Shizuoka, Japan [Y.M.]
}

\begin{abstract}
Summary
This study explores the effects of several divalent metal ions on the in vitro production of cyclic AMP, cyclic GMP, and testosterone by rat testicular tissue and on the amount of binding of $\left[{ }^{125}\right.$ I] human chorionic gonadotropin (hCG) in the testis. $\mathrm{Zn}^{2+}$ at concentrations of $10^{-6}$ to $10^{-4} \mathrm{M}$ enhanced the hCG-stimulated production of cyclic AMP and testosterone, but only in the presence of $\mathrm{Ca}^{2+}$. $\left.{ }^{125} \mathrm{I}\right] \mathrm{hCG}$ binding to rat testicular tissue was not affected by $\mathrm{Zn}^{2+} . \mathrm{Cu}^{2+}, \mathrm{Ni}^{2+}, \mathrm{Co}^{2+}$, and $\mathrm{Mn}^{2+}$ did not increase cyclic AMP or testosterone production in concentrations of $10^{-7}$ to $10^{-3} \mathrm{M}$ and even inhibited them at a high concentration $\left(10^{-2}\right.$ M). Cyclic GMP production was not affected by these divalent ions. These results suggest that $\mathrm{Zn}^{2+}$ may play an important role in rat testicular steroidogenesis.
\end{abstract}

\section{Abbreviations}

hCG, human chorionic gonadotropin

KRBB, Krebs Ringer bicarbonate buffer

PBS, phosphate buffered saline

Trace metal ions are known to influence hormones at several stages of action, including hormone secretion and activity and binding to target tissue. Conversely, hormones influence trace metal ion metabolism at several levels, including excretion and transport of ions (9). Zinc ion plays an important role in growth and sexual development. A deficiency of zinc not only reduces zinc levels in the reproductive tissues but also impairs the responsiveness of the Leydig cells to gonadotropins, and thus may cause primary hypogonadism in humans as well as in experimental animals $(1,14,28)$. Furthermore, constitutionally short boys at Tanner stages 1 and 2 have lower zinc levels in their serum and hair and lower serum testosterone levels than those at Tanner stages 3 to 5 (3). These results suggest that the relative testosterone deficiency in constitutional growth delay may result in decreased zinc levels, which in turn could cause a further delay in sexual development and growth.

Recent studies indicate that the uptake of hCG in the testes of zinc-injected rats is significantly higher than that in controls (11, 12 ) and that $\mathrm{Zn}^{2+}$ affects adenylate cyclase activity in bovine and human sperm $(2,8)$ and liver $(16)$. We investigated that the effects of various divalent metal ions, including $\mathrm{Zn}^{2+}$, on cyclic AMP, cyclic GMP, and testosterone production stimulated by $\mathrm{hCG}$ and the effect of $\mathrm{Zn}^{2+}$ on the binding of [ $\left.{ }^{125} \mathrm{I}\right] \mathrm{hCG}$ to rat testicular tissue in vitro.

\section{MATERIALS AND METHODS}

Male Wistar rats were reared in individual stainless steel cages and fed an adequate amount of zinc (43 ppm) ad libitum for 4 wk before the study. Deionized water was also provided ad libitum. The mean weight was $242 \pm 16 \mathrm{~g}$ at the time of study. They were anesthetized with ether. Both testes were removed, decapsulated, and sectioned into 50 - $\mathrm{mg}$ slices from one rat for each experiment. Four tissue slices from each rat were used for each concentration of each metal in the presence or absence of hCG. Studies were repeated at least once and similar results were obtained in each metal experiment. This paper describes one of three similar zinc experiments. Sixteen rats were used in all these studies. Each slice was placed in a glass tube $(12 \times 90 \mathrm{~mm})$ containing $500 \mu \mathrm{l}$ of $\mathrm{KRBB}, \mathrm{pH} 7.4$ and preincubated for 30 min at $4^{\circ} \mathrm{C}$ in a metabolic shaker at $120 \mathrm{cycle} / \mathrm{min}$ in an atmosphere of $95 \% \mathrm{O}_{2}-5 \% \mathrm{CO}_{2}$. The tubes were immediately centrifuged at $1500 \mathrm{~g}$ for $5 \mathrm{~min}$, and the supernatant was aspirated. To each tube was added $500 \mu$ l of KRBB, pH 7.4, containing 1 $\mathrm{mg} / \mathrm{ml}$ of glucose, $2 \mathrm{mM}$ theophylline, and various divalent cations with or without $10 \mathrm{ng}$ of hCG. The final $\mathrm{pH}$ of the solution was 7.4. The specimens were incubated at $34^{\circ} \mathrm{C}$ for $3 \mathrm{~h}$, then placed in an ice bath. The tubes were centrifuged at $1500 \mathrm{~g}$ for $15 \mathrm{~min}$ at $4^{\circ} \mathrm{C}$, and the supernatant was assayed for cyclic AMP, cyclic GMP and testosterone. Similar experiments were performed in a $\mathrm{Ca}^{2+}$-free medium. Inasmuch as hCG-induced elevations of intra- and extracellular cyclic AMP and extracellular testosterone have been observed $(6,7,23)$, we used the incubation media for cyclic AMP, cyclic GMP, and testosterone assay. Both cyclic AMP and cyclic GMP were determined as described previously $(18,24,27)$, and testosterone by Nieschlag's method (20).

Samples for each experiment were processed in the same assay. For cyclic AMP, cyclic GMP, and testosterone assays, the interassay coefficients of variation were 9,7 , and $7 \%$, respectively, and the intraassay coefficients of variation were 8,10 , and $8 \%$, respectively. Statistical analysis was performed with Student's $t$ test. In our previous in vitro studies of hCG-induced elevations of cyclic AMP and testosterone during incubation of rat testicular slices with increasing concentrations of hCG $(0-100 \mathrm{ng} / 500 \mu \mathrm{l})$, dose-related increases of cyclic AMP were observed, but the elevation of testosterone reached its maximum at $1 \mathrm{ng}$ of hCG and remained constant despite increasing cyclic AMP production with high levels of hCG $(10,19)$. Similar discrepancies between cyclic AMP and testosterone production in the rat testis during incubation with hCG in vitro were also observed by Dufau et al. $(6,7)$; therefore, we used $10 \mathrm{ng}$ of hCG in the incubation medium. $\left[{ }^{125} \mathrm{I}\right] \mathrm{hCG}$ binding studies in rat testicular tissue were performed in two different rats, and the results were similar. One of the two studies is described in this paper. Incubations were performed in duplicate for each experiment. [ $\left.{ }^{125} \mathrm{I}\right] \mathrm{hCG}$ binding to rat testicular tissue was assessed as follows: decapsulated right and left testes of one rat were homogenized in PBS, pH 7.4 in a tissue blender at $13,000 \mathrm{r} / \mathrm{min}$ for $1 \mathrm{~min}$. After centrifugation at $1500 \mathrm{~g}$ for $15 \mathrm{~min}$, the pellet was resuspended in $0.25 \mathrm{M}$ sucrose 
containing $10 \mathrm{mM}$ Tris- $\mathrm{HCl}$ buffer, $\mathrm{pH} \mathrm{7.4.} \mathrm{Aliquots} \mathrm{of} \mathrm{the}$ resuspended pellet, $\left[{ }^{125} \mathrm{I}\right] \mathrm{hCG}$ prepared by the lactoperoxidase method of Miyachi et al. (17) (20,000 count/min, equivalent to $1.23 \mathrm{ng}$ ), $500 \mathrm{pg}$ to $100 \mathrm{ng}$ of unlabeled hCG and PBS containing $0.1 \%$ bovine serum albumin were adjusted to a final volume of $500 \mu \mathrm{l}$ at the required concentration of $\mathrm{Ca}^{2+}\left(10^{-3} \mathrm{M}\right)$ and $\mathrm{Zn}^{2+}$ $\left(10^{-5} \mathrm{M}\right)$ and then incubated in duplicate at room temperature for $18 \mathrm{~h}$.

At the end of the incubation, $100 \mu \mathrm{l}$ of $1 \%$ bovine $\gamma$-globulin saline solution and $1 \mathrm{ml}$ of $20 \%$ polyethyleneglycol solution were added to the tubes and centrifuged at $1500 \mathrm{~g}$ for $15 \mathrm{~min}$ at $4^{\circ} \mathrm{C}$. After the supernatant solution was aspirated, the tissue-bound radioactivity present in each tube was determined in an autowell gammaspectrometer. The binding data were analyzed by Scatchard plots.

Serum was collected from 18 rats and the zinc content was determined by a flameless atomic absorption spectrophotometer (Model 170-70, Hitachi, Japan). Chloride salts of $\mathrm{Zn}^{2+}, \mathrm{Cu}^{2+}$, $\mathrm{Ni}^{2+}, \mathrm{Co}^{2+}$, and $\mathrm{Mn}^{2+}$ were obtained from Nakarai Chemicals (Kyoto, Japan) and added to the medium to give the required concentrations of $10^{-7}$ to $10^{-2} \mathrm{M}$. hCG (CR 117), with a biologic activity of $10,000 \mathrm{IU} / \mathrm{mg}$, was provided by Dr. G. T. Ross. Acidwashed instruments and basal incubation media were found to be free of these metals. KRBB contained $1.3 \times 10^{-3} \mathrm{M}$ of $\mathrm{Ca}^{2+}$. $\mathrm{KRBB}$ without $\mathrm{CaCl}_{2}$ was used as a $\mathrm{Ca}^{2+}$-free medium.

\section{RESULTS}

The in vitro basal production of cyclic AMP and testosterone in rat testicular fragments was not affected by $\mathrm{Zn}^{2+}$ at concentrations of $10^{-7}$ to $10^{-3} \mathrm{M}$ whereas the hCG-stimulated production of cyclic AMP and testosterone was enhanced significantly in the presence of $\mathrm{Zn}^{2+}\left(10^{-6}\right.$ to $\left.10^{-4} \mathrm{M}\right)$ (Fig. 1). At a concentration of $10^{-4} \mathrm{M} \mathrm{Zn}^{2+}$, hCG-stimulated cyclic AMP production was increased, whereas testosterone production was not. Furthermore, at $10^{-3} \mathrm{M} \mathrm{Zn}^{2+}$, hCG-stimulated cyclic AMP production was similar to that in the controls, but testosterone production was not affected by hCG. These results suggest that concentrations of $10^{-4}$ and $10^{-3} \mathrm{M}$ of $\mathrm{Zn}^{2+}$ may inhibit the enzymes involved in the synthesis of testosterone. An extremely high concentration of $\mathrm{Zn}^{2+}\left(10^{-2} \mathrm{M}\right)$ markedly reduced the production of cyclic AMP and of testosterone both in the presence and in

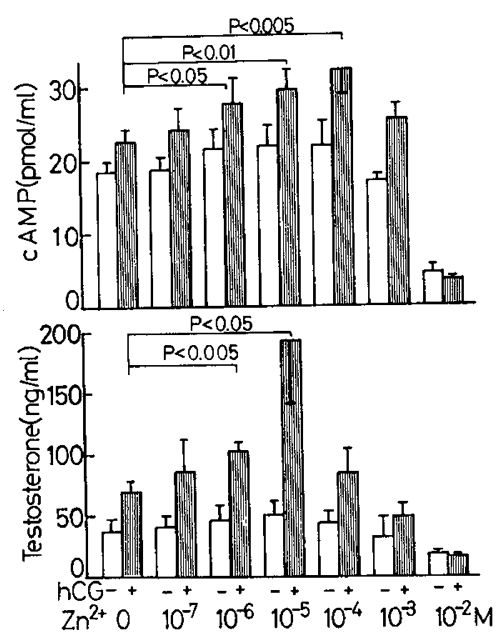

Fig. 1. Effect of $\mathrm{Zn}^{2+}\left(0-10^{-2} \mathrm{M}\right)$ on the in vitro production of cyclic $\mathrm{AMP}$ and testosterone during incubation of rat testis slices in medium containing $1.3 \times 10^{-3} \mathrm{M}$ of $\mathrm{Ca}^{2+}$ with or without $10 \mathrm{ng}$ of hCG. Each bar shows the mean \pm SD of quadruplicate incubations of testicular slices from the same rat. The hCG-stimulated production of cyclic AMP and testosterone is increased significantly in the presence of both $\mathrm{Zn}^{2+}$ $\left(10^{-6}\right.$ to $\left.10^{-4} \mathrm{M}\right)$ and $\mathrm{Ca}^{2+}\left(1.3 \times 10^{-3} \mathrm{M}\right) . P$ values show the differences in hCG-stimulated production of cyclic AMP and testosterone in the presence of $\mathrm{Zn}^{2+}\left(10^{-6}\right.$ to $\left.10^{-4} \mathrm{M}\right)$ and in the absence of $\mathrm{Zn}^{2+}$.

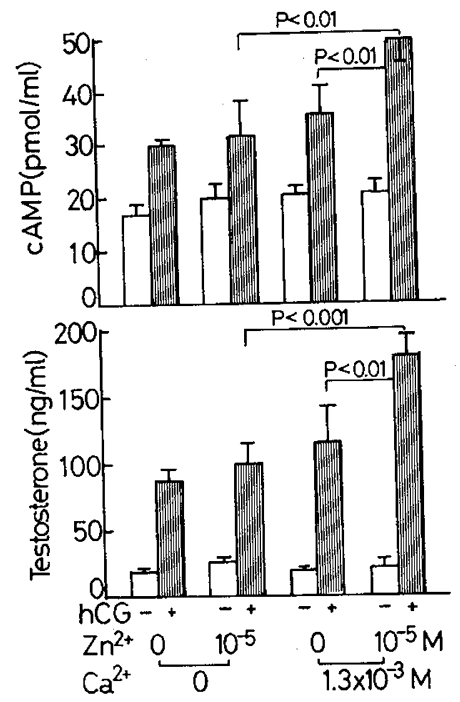

Fig. 2. Effect of $\mathrm{Zn}^{2+}\left(0\right.$ or $\left.10^{-5} \mathrm{M}\right)$ on the in vitro production of cyclic AMP and testosterone during incubation of rat testis slices with or without $10 \mathrm{ng}$ of hCG in the presence or absence of $\mathrm{Ca}^{2+}\left(1.3 \times 10^{-3} \mathrm{M}\right)$. Each bar shows the mean \pm SD of quadruplicate incubations of testicular slices from the same rat. The enhancement by $\mathrm{Zn}^{2+}$ of the hCG-stimulated production of cyclic AMP and testosterone in an incubation medium containing $1.3 \times 10^{-3} \mathrm{M}$ of $\mathrm{Ca}^{2+}$ shown in Figure 1 is lost in the absence of $\mathrm{Ca}^{2+} \cdot \mathrm{Zn}^{2+}$ may act synergistically with $\mathrm{Ca}^{2+} . P$ values show the difference of hCG-stimulated production of cyclic AMP and testosterone with and without $\mathrm{Zn}^{2+}\left(10^{-5} \mathrm{M}\right)$ in the presence or absence of $\mathrm{Ca}^{2+}\left(1.3 \times 10^{-3} \mathrm{M}\right)$.

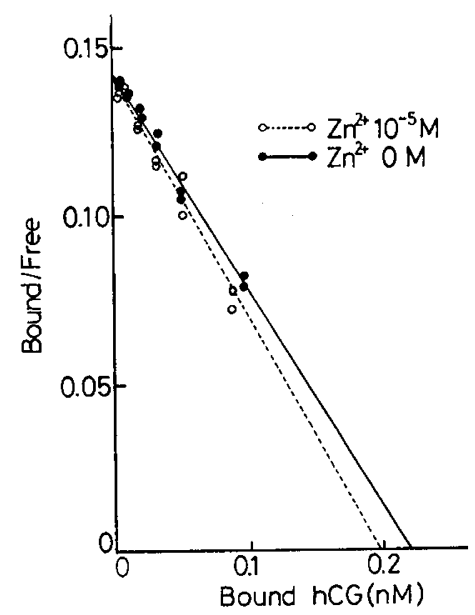

Fig. 3. Scatchard plot analyses of [ $\left.{ }^{125} \mathrm{I}\right] \mathrm{hCG}$ in rat testicular tissue. The rat testicular suspension was prepared and incubated with labeled $(20,000$ count $/ \mathrm{min})$ and unlabeled (500 pg to $100 \mathrm{ng}) \mathrm{hCG}$ and $\mathrm{Ca}^{2+}$ $\left(10^{-3} \mathrm{M}\right)$ in the presence or absence of $\mathrm{Zn}^{2+}\left(10^{-5} \mathrm{M}\right)$. The studies were carried out in duplicate with the same testicular suspensions. Both binding capacity and binding affinity were unaffected by $\mathrm{Zn}^{2+}$.

the absence of hCG. The enhancement by $\mathrm{Zn}^{2+}$ on the effect of hCG on testicular steroidogenesis, however, was lost completely in the absence of $\mathrm{Ca}^{2+}$ (Fig. 2).

A study of the binding of $\left[{ }^{125} \mathrm{I}\right] \mathrm{hCG}$ to rat testis showed that both binding capacity and binding affinity were unaffected by $\mathrm{Zn}^{2+}$ (Fig. 3). The ions, $\mathrm{Cu}^{2+}, \mathrm{Ni}^{2+}, \mathrm{Co}^{2+}$, and $\mathrm{Mn}^{2+}$ had no effect on basal or hCG-stimulated cyclic AMP or testosterone production in concentrations of $10^{-7}$ to $10^{-3} \mathrm{M}$, but inhibited them at the high concentration of $10^{-2} \mathrm{M}$ (data not shown). Divalent ions had no effect on the production of cyclic GMP (data not shown). Serum zinc concentration was $138 \pm 12 \mu \mathrm{g} / \mathrm{dl}$. 


\section{DISCUSSION}

All experiments were performed in zinc-adequate rats fed a zinc-adequate diet $(43 \mathrm{ppm})$ because serum zinc concentration $(138 \pm 12 \mu \mathrm{g} / \mathrm{dl})$ was very similar to that of rats fed $41 \mathrm{ppm}$ of zinc (136 $\pm 3 \mu \mathrm{g} / \mathrm{dl})$ reported by Koo and Williams (13). The response of cyclic AMP and testosterone to hCG was augmented in the presence of $\mathrm{Zn}^{2+}\left(10^{-6}\right.$ to $\left.10^{-4} \mathrm{M}\right)$, but this augmentation did not occur in the absence of $\mathrm{Ca}^{2+}$, indicating that $\mathrm{Zn}^{2+}$ acts synergistically with $\mathrm{Ca}^{2+}$.

The increase of hCG-stimulated cyclic AMP and testosterone production by $\mathrm{Zn}^{2+}$ in the presence of $\mathrm{Ca}^{2+}$ cannot be fully explained, but the following four possibilities are suggested. First, $\mathrm{Zn}^{2+}$ may activate adenylate cyclase and consequently stimulate steroidogenesis in the rat testis. Braun (2) observed that $\mathrm{Zn}^{2+}$ activated bovine sperm adenylate cyclase, probably due to a $\mathrm{Zn}^{2+}$-ATP substrate, which might be the physiologic substrate complex for bovine sperm adenylate cyclase, and that the addition of $\mathrm{Ca}^{2+}$ acted synergistically with $\mathrm{Zn}^{2+}$ in stimulating this enzyme in bovine sperm. He speculated that $\mathrm{Ca}^{2+}$ might stimulate the translocation of $\mathrm{Zn}^{2+}$ to the regulatory site, catalytic site and/or transducer system in the plasma membrane. Conversely, $\mathrm{Zn}^{2+}$ might affect intracellular $\mathrm{Ca}^{2+}$ availability and distribution. On the contrary, Haesungcharern and Chulavatnatol (8) and Malmquist et al. (16) reported that human sperm and liver adenylate cyclase was inhibited by $\mathrm{Zn}^{2+}$. These discrepancies may be due to species differences and/or experimental conditions. For instance, in Braun's experiments using bovine sperm, $5 \mathrm{mM}$ of $\mathrm{Zn}^{2+}$ activated adenylate cyclase and acted synergistically with $5 \mathrm{mM}$ of $\mathrm{Ca}^{2+}(2)$; whereas in Haesungcharern and Chulavatnatol's study using human sperm, $2.5 \mathrm{mM}$ of $\mathrm{Zn}^{2+}$ showed pronounced inhibition of adenylate cyclase, but the enzyme was insensitive to $\mathrm{Ca}^{2+}(8)$. Furthermore, in studies (16) using human liver membranes, adenylate cyclase stimulated by either glucagon or fluoride was inhibited by $\mathrm{Zn}^{2+}(12.5-100 \mu \mathrm{M})$, but the effect of $\mathrm{Ca}^{2+}$ was not investigated.

Second, $\mathrm{Zn}^{2+}$ may inhibit the degradation of the $\mathrm{hCG}$ receptor molecule, or may stabilize the receptor-hormone complex and enhance the biologic activity of hCG-receptor complexes. This possibility is supported by the observation of Rajaniemi et al. (22) that a portion of the receptor-bound hCG may dissociate from the luteal cell surface as a high molecular weight complex and that heavy metal ions such as $\mathrm{Zn}^{2+}$ can prevent this kind of hormone dissociation. Kellokumpu and Rajaniemi $(11,12) \mathrm{dem}-$ onstrated that the intratesticular administration of $\mathrm{ZnCl}_{2}$ in vivo led to a greater uptake of hCG in zinc-treated testes than in saline-treated testes and that the dissociation of the hCG-receptor complex was inhibited by $\mathrm{Zn}^{2+}$. In our study the in vitro binding of $\left[{ }^{125} \mathrm{I}\right] \mathrm{hCG}$ to rat testicular tissue was unaffected in the presence of both $\mathrm{Zn}^{2+}$ and $\mathrm{Ca}^{2+}$. Kellokumpu and Rajaniemi (12) observed that in vitro binding studies $\mathrm{Cd}^{2+}$ reduced rather than increased the affinity of hCG or the number of specific binding sites, but the effect of $\mathrm{Zn}^{2+}$ was not studied. The reasons for the discrepancies between our in vitro findings and the in vivo and in vitro results of Kellokumpu and Rajaniemi $(11,12)$ are not clear at the present time, but they may be due to differences in the experimental conditions. For instances, in the in vivo studies of Kellokumpu and Rajaniemi $\mathrm{ZnCl}_{2}$ was injected directly into the rat testes, and labeled and unlabeled hCG was administered via the tail vein; then the testes were removed 1 or $3 \mathrm{~h}$ after hCG injection and were tested for tissue-bound radioactivity $(11,12)$. In our in vitro experiments aliquots of the resuspended pellet of the rat testis were incubated with labeled and unlabeled hCG, $\mathrm{ZnCl}_{2}$ and $\mathrm{CaCl}_{2}$ for $18 \mathrm{~h}$ at room temperature, and tissue-bound radioactivity was counted. They also observed that some of the receptor-bound hCG from rat testicular particles, prelabeled in vivo with $\left[{ }^{125} \mathrm{I}\right] \mathrm{hCG}$, dissociated under in vitro conditions without $\mathrm{Ca}^{2+}$, perhaps via fragmentation of the receptor molecule. This process was significantly inhibited by the addition of $\mathrm{Zn}^{2+}$ to the incubation medium $(11,12)$. They speculated that $\mathrm{Zn}^{2+}$ could prevent fragmentation of the receptor by binding directly to the bound hormone or the receptor molecule itself $(11,12)$.
Third, $\mathrm{Zn}^{2+}$ may influence the lipid components, thiol groups of protein in the plasma membrane and several enzymes attached to the plasma membrane, such as ATPase and phospholipase $\mathrm{A}_{2}$ $(4,5)$, which could also explain its effect on hormone-receptor interaction. Cytoskeletal components, such as microtubules and microfilaments, are involved in many cellular functions, i.e., cell movement, phagocytosis, secretion, mitosis, receptor distribution and some membrane-linked physiologic processes. $\mathrm{Ca}^{2+}$ plays an essential role in these functions $(4,5,15,29) . \mathrm{Zn}^{2+}$ may also affect these components, directly or indirectly, by influencing $\mathrm{Ca}^{2+}$ metabolism in cells and changing the excitability of the plasma membrane, which could also explain its effect on hormone metabolism although the exact mechanism whereby this occurs in the testis is not clear. Kellokumpu and Rajaniemi (12) speculated that some hCG-receptor complexes might be bound tightly to cytoskeletal components because only about $10-20 \%$ of $\left[{ }^{125} \mathrm{I}\right] \mathrm{hCG}$-receptor complexes were solubilized with $1 \%$ Triton $\mathrm{X}-100$ and that heavy metals such as $\mathrm{Zn}^{2+}$ might affect interactions between hormone-receptor complexes and cytoskeletal components.

Finally, zinc plays an essential role in many vital enzymesincluding DNA polymerase (26), DNA-dependent RNA polymerase (25), and thymidine kinase (21)-and is normally present in high concentrations in the reproductive organs. Inasmuch as these enzymes are important for nucleic acid and protein synthesis and cell division, zinc appears to be essential for the integrity of hormone metabolism in these organs. Some of the key enzymes of steroidogenesis may also be zinc-dependent.

Other divalent metal ions, $\mathrm{Cu}^{2+}, \mathrm{Ni}^{2+}, \mathrm{Co}^{2+}$, and $\mathrm{Mn}^{2+}$ in concentrations of $10^{-7}$ to $10^{-3} \mathrm{M}$ did not produce any increase of either basal or hCG-stimulated cyclic AMP or testosterone. At high concentration $\left(10^{-2} \mathrm{M}\right)$ the production of cyclic AMP and testosterone was inhibited, as with $\mathrm{Zn}^{2+}$. This result may be due mainly to a gonadotoxic effect of these heavy metals at high concentrations that interfere with $\mathrm{hCG}$ binding sites. $\mathrm{ZnCl}_{2}$ and $\mathrm{CuCl}_{2}$ at only $10^{-2} \mathrm{M}$ precipitated out of the solution and these factors may be some of the causes of the inhibition at high concentrations $\left(10^{-2} \mathrm{M}\right)$. Inactivation of hCG-receptor protein or impairment of polysome aggregation may be another cause of the inhibition of cyclic AMP and testosterone production by high concentrations of heavy metals. We conclude that $\mathrm{Zn}^{2+}$ acts synergistically with $\mathrm{Ca}^{2+}$ and plays an essential role in testicular function.

\section{REFERENCES AND NOTES}

1. Abbasi, A. A., Prasad, A. S., Rabbani, P., and DuMouchelle, E.: Experimental zinc deficiency in man. Effect on testicular function. J. Lab. Clin. Med., 96: 544 (1980).

2. Braun, T.: The effect of divalent cations on bovine spermatozoal adenylate cyclase activity. J. Cyclic Nucleotide Res., 1: 271 (1975).

3. Castro-Magana, M., Collipp, P. J., Chen, S. Y., Cheruvanky, T., and Maddaian, V. T.: Zinc nutritional status, androgens, and growth retardation. Am. J. Dis. Child., 134: 322 (1981).

4. Chvapil, M.: New aspects in the biological role of zinc: A stabilizer of macromolecules and biological membranes. Life Sci., 13: 1041 (1973).

5. Chvapil, M.: Effect of zinc on cells and biomembrane. Med. Clin. N. Am., 60: 799 (1976).

6. Dufau, M. L., Watanabe, K., and Catt, K. J.: Stimulation of cyclic AMP production by the rat testis during incubation with hCG in vitro. Endocrinology, 96: 6 (1973).

7. Dufau, M. L., Tsuruhara, T., Horner, K. A., Podesta, E., and Catt, K.: Intermediate role of adenosine $3^{\prime}: 5^{\prime}$-cyclic monophosphate and protein kinase during gonadotropin-induced steroidogenesis in testicular interstitial cells. Proc. Natl. Acad. Sci. USA, 74: 3419 (1977).

8. Haesungcharern, A. and Chulavatnatol, M.: Inhibitors of adenylate cyclase from ejaculated human spermatozoa. J. Reprod. Fert., 53: 59 (1978).

9. Henkin, R. I.: Trace metals in endocrinology. Med. Clin. N. Am., 60: 779 (1976).

10. Kawamura, H., Tanaka, K., Miyoshi, A., Kato, K., and Miyachi, Y.: Autoregulation of the gonadotropin receptors in rat testes after human chorionic gonadotropin administration. Folia Endocrinol. Jap., 57: 1199 (1981).

11. Kellokumpu, S. and Rajaniemi, H.: Effect of zinc on the uptake of human chorionic gonadotropin (hCG) in rat testis and testosterone response in vivo. Biol. Reprod., 24: 298 (1981).

12. Kellokumpu, S. and Rajaniemi, H.: Dissociation of receptor-bound human chorionic gonadotropin from rat testicular membranes in vitro as a high molecular weight complex and its inhibition by heavy metals and alkylating 
agents. Biochem. Biophys. Acta, 718: 26 (1982).

13. Koo, S. I. and Williams, D. A.: Relationship between the nutritional status of zinc and cholesterol concentration of serum lipoproteins in adult male rats. Am. J. Clin. Nutr., 34: 2376 (1981)

14. Lei, K. Y., Abbasi, A., and Prasad, A. S.: Function of pituitary-gonadal axis in zinc-deficient rats. Am. J. Physiol., 230: 1730 (1976)

15. Loor, F.: Plasma membrane and cell cortex interactions in lymphocyte functions. Adv. Immunol., 30: 1 (1980).

16. Malmquist, J., Israelsson, B., and Ljungqvist, U.: Inhibition of human liver membrane adenylate cyclase by zinc ions. Horm. Metab. Res., 11: 530 (1979).

17. Miyachi, Y., Vaitukaitis, J. L., Nieschlag, E., and Lipsett, M. B.: Enzymatic radioiodination of gonadotropins. J. Clin. Endocr., 34: 23 (1972).

18. Miyachi, Y., Mizuchi, A., and Sato, K.: Preparation of iodinated cyclic GMP derivates by a lactoperoxidase method. Anal. Biochem., 77: 429 (1977).

19. Miyachi, Y. and Kawamura, H.: Gonadotropin. Jap. J. Clin. Med., 39: 2954 (1981).

20. Nieschlag, E. and Loriaus, D. L.: Radioimmunoassay for plasma testosterone. Z. klin. chem. klin. Biochem., 10: 164 (1972).

21. Prasad, A. S. and Oberleas, D.: Thymidine kinase activity and incorporation of thymidine into DNA in zinc deficient tissue. J. Lab. Clin. Med., 83: 634 (1974).

22. Rajaniemi, H., Manninen, M., Metsikkö, K., and Huhtaniemi, L.: Dissociation of human choriogonadotropin from the pseudopregnant rat ovary as a complex to a receptor fragment during perifusion and incubation. Biochem. Biophys. Acta, 714: 271 (1982).

23. Sato, K., Miyachi, Y., Ohsawa, N., and Kosaka, K.: In vitro stimulation of steroidogenesis in rat testis by cholera enterotoxin. Biochem. Biophys. Res.
Commun., 62: 696 (1975)

24. Sato, K., Miyachi, Y., Mizuchi, A., Ohsawa, N., and Kosaka, K.: Enzymatic radioiodination of succinyl cyclicAMP tyrosine methylester by lactoperoxidase and radioimmunoassay for cyclicAMP. Endocrinol. Jap., 23: 251 (1976).

25. Scrutton, M. C., Wu, C. W., and Goldthwait, D. A.: The presence and possible role of zinc in RNA polymerase obtained from Escherichia coli. Proc. Natl. Acad Sci. USA 68:2497 (1971).

26. Slater, J. P., Mildvan, A. S., and Loeb, L. W.: Zinc in DNA polymerases. Biochem. Biophys. Res. Commun., 44: 37 (1971).

27. Steiner, A. L., Parker, C. W., and Kipnis, D. M.: Radioimmunoassay for cyclic nucleotides. I. Preparation of antibodies and iodinated cyclic nucleotides. J. Biol. Chem., 247: 1106 (1972)

28. Underwood, E. J.: Zinc. In: Trace elements in human and animal nutrition. 4th Ed.: pp. 196-242 (Academic Press, New York, 1977).

29. Weatherbee, J. A.: Membranes and cell movement: Interaction of membranes with the proteins of the cytoskeleton. In: A. L. Muggleton-Harris: International Review of Cytology. Suppl. 12. pp. 113-176 (Academic Press, New York, 1981).

30. Requests for reprints should be addressed to: Dr. Yoshikazu Nishi, Department of Pediatrics, Hiroshima University School of Medicine, 1-2-3 Kasumi, Minami-ku, Hiroshima 734, Japan.

31. This research was supported in part by a Grant-in-Aid for Scientific Research (Project No. 57770633) from the Ministry of Education, Science and Culture of Japan and a Grant-in-Aid from Morinaga Hoshikai.

32. We are grateful to Dr. Alice $S$. Cary for assistance in preparing this manuscript.

33. Received for publication November 16, 1982.

34. Accepted for publication June 6, 1983 .

\title{
Kinetics of Intestinal Calcium Transport during Maturation in Rats
}

\author{
FAYEZ K. GHISHAN, ${ }^{(18)}$ PAUL PARKER, SHARON NICHOLS, AND ANASTACIO HOYUMPA \\ Vanderbilt University Medical Center and VA Medical Center, Departments of Pediatrics and Medicine, \\ Nashville, Tennessee, USA
}

\section{Summary}

Young animals absorb and retain more calcium (Ca) than their older counterparts. The mechanism(s) for this age-related difference and the kinetics of intestinal calcium transport during maturation are not known. We determined, therefore, the unidirectional uptake and the transmural flux of $\left[{ }^{45} \mathrm{Ca}\right]$ in everted duodenal and jejunal sacs of suckling, weanling, adolescent, and adult rats using $\left[{ }^{3} \mathbf{H}\right]$ dextran as a marker of adherent mucosal volume. These measurements were carried out over a wide range of Ca concentrations $(0.5-30 \mathrm{mM})$. Results indicate an evolving pattern of intestinal calcium transport with different kinetic characteristics emerging as the animals matured. The active component of transport became more pronounced with increasing age. In adult rats $\mathrm{Km}$ and $\mathrm{Jmax}$ of $\left[{ }^{45} \mathrm{Ca}\right]$ duodenal and jejunal uptake were several-fold greater than corresponding values for suckling rats. Transport at higher calcium concentrations (10$30 \mathrm{mM}$ ) was non-saturable, and the 'permeability coefficient decreased with age. The transition to a more saturable process occurred around the time of weaning. These findings suggest that intestinal calcium transport is characterized by a maturation pattern that starts with a predominantly passive system during infancy and changes to a saturable active mechanism during maturation.
Studies of calcium balance indicate that calcium is absorbed and retained to a much greater degree in young growing animals than in their older counterparts. This suggests that calcium absorption and retention are governed by the particular need of the organism at the time, and requires a better understanding of calcium absorption.

The absorption of calcium from the intestine has been shown to possess characteristics of both active $(9,11,12)$ and passive (7) processes. In adult rats, and other animals, the rate of calcium transport is greatest in the proximal small intestine and decreases along the distal length of the gut. The uptake of calcium into the intestinal tissue is saturable and is adversely affected by anoxia, low temperature, and various metabolic inhibitors (13). These observations suggest an energy-requiring active process. Furthermore, the active transport of calcium appears to be dependent on $1,25-(\mathrm{OH})_{2}$ vitamin $\mathrm{D}_{3}(10)$. Features of active transport are generally seen at calcium concentrations below $10 \mathrm{mM}$. At higher concentrations, calcium transport is predominantly a passive process (17). These studies, however, were carried out using adult animals, and the possibility that calcium transport in the very young may be unique has received little attention. The present studies were undertaken to characterize calcium transport in segments of the duodenum and jejunum of rats during maturation. 